\title{
Study of Life Satisfaction and Determining Factors Among Yemeni Students Residing in Morocco
}

\author{
Abdulrahman taresh yahya OMAIR ${ }^{1}$, Alemad ALI ${ }^{2}$, Abdelmajid SOULAYMANI ${ }^{3}$ andAberrazzak KHADMAOUI
}

${ }^{1}$ BHL; Biology Department faculty of science, Yemen..

${ }^{2}$ biology and health laboratory; Biology Department faculty of science, university ibn tofail; kénitra morocco

${ }^{3}$ biology and health laboratory; Biology Department faculty of science, university ibn tofail; kénitra morocco; ORCID: 00000002-0964-1029.

${ }^{4}$ biology and health laboratory; Biology Department faculty of science, university ibn tofail; kénitra morocco;; ORCID: 00000003-2993-9049.

\begin{abstract}
A student's life satisfaction is marked by four themes: the relationship to studies, budget, housing and health state. The objective of our work is to establish a profile of life satisfaction and support of Yemeni students residing in Morocco. The choice is made on a prepared questionnaire, which the characteristics of reliability, loyalty are important. The results show that $13.8 \%(n=25)$ of Yemeni respondents residing in Morocco showed great self-dissatisfaction against $16.5 \%(n=32)$ who responded satisfied with their life. However, $14.8 \%(n=29)$ of the respondents showed great dissatisfaction with the support against $13.8 \%(n=27)$ who responded satisfied with the support of their family and friends. Two factors have been shown to be associated with this behavior, namely marital status and city of residence. Therefore, the Moroccan and Yemeni authorities should face these risk factors by presenting adequate solutions so that these students lead a normal life.
\end{abstract}

Keywords: life satisfaction; support;scale; determining factor; Student; Yemen

\section{Introduction}

According to the National Student Living Conditions survey (2016), four themes are sufficient to assess the state of satisfaction of a student's life: the relationship to studies, budget, housing and health state, the objective is to "monitor over time the evolution of student living conditions". Much research has focused on the study of student satisfaction / dissatisfaction such as [2-4]. Dissatisfaction is a cause of stress which in turn leads to psychological and / or psychosomatic disorders [5], 2002). According to UNESCO, the annual growth rate of the number of foreign students is $7 \%$ between 1960 and 2001 and at 3\% for the period 1985-2001. Over time, these students find difficulties in their extracurricula activities (social, health, cultural and sports activities, plus housing and transportation services) [2,6]. Morocco has become a center for foreign students from almost all continents. This is explained by two essential reasons, including the singularity of the higher education system in Morocco and the particularity of international student mobility facilitated by the cooperation policy. During the last decade, the number of foreign students enrolled in Moroccan public institutions has grown steadily. It has, in fact, evolved from 2,508 during the academic year 1998-1999 to 11,577 during the year 2010-2011[7,8]. Despite the services provided by the Moroccan Table 1. Definition of Satisfaction Items authorities, the well-being felt by these students depends on living conditions (material, health, support, etc.).

The present work is establishing a profile of life satisfaction in a group of Yemeni students residing in Morocco as well as the search for determining factors.

\section{Material and Methods}

\subsection{Population and Study Area}

This is a cross-sectional study carried out during 2017 and concerns 197 Yemeni students living in three Moroccan zones (Rabat / sale/ kenitra); (Tangier / Tetouan) and Grand Casa Blanca. The choice of respondents was free and random and concerns both sexes (158 male and 39 female).

\subsection{Exploitation tool (questionnaire)}

The questions were prepared by the authors and put to the students outside of exam or lecture periods). The questions are grouped into two dimensions; these are dimension I (satisfaction) (5items) and dimension II (support) (5items) (table 1).

\begin{tabular}{|l|l|l|}
\hline D1 & 1 & In general, how satisfied are you with your life? \\
\cline { 2 - 3 } & 2 & How satisfied are you with yourself? \\
\cline { 2 - 3 } & 3 & How satisfied are you with your abilities? \\
\cline { 2 - 3 } & 4 & How satisfied are you with the conditions of your living place? \\
\hline
\end{tabular}




\begin{tabular}{|l|l|l|}
\hline & 5 & How satisfied are you with your financial situation? \\
\hline D2 & 6 & How satisfied are you with your personal relationships? \\
\cline { 2 - 3 } & 7 & How satisfied are you with the support you get from your family? \\
\cline { 2 - 3 } & $\mathbf{8}$ & How satisfied are you with the support you get from your friends? \\
\cline { 2 - 3 } & 9 & How satisfied are you with your ability to provide for or support others? \\
\cline { 2 - 3 } & $\mathbf{1 0}$ & Do you feel happy about your relationship with your family members? \\
\hline
\end{tabular}

To break out the categories of these dimensions, we followed the Zscore method which is based on the transformation of the scores corresponding to centered values reduced according to the following levels:

*<- 1 Z standard deviation: unsatisfied people

* $-1 \mathrm{Z}$ standard deviation $<>+1 \mathrm{Z}$ standard deviation for people to watch

* > 1Z standard deviation: satisfied people

The choice of the answer is according to likert scale which varies from too 'dissatisfied' to too 'satisfied' by granting them indices respectively from 1 to 5.A telephone conversation took place with each student to explain the objective and interest of the study as well as the ethical aspects, including the voluntary service and anonymity of this survey, and to set an appointment for the completion of the questionnaire.

Table 2. Sociodemographic characteristics of the respondents

\begin{tabular}{|l|l|l|}
\hline variable & modality & frequency \\
\hline \multirow{4}{*}{ City } & Rabat./Sale/kenitra & $\mathbf{6 2 , 9 4 \%}$ \\
\cline { 2 - 3 } & Tanger/Tetouan & $\mathbf{1 8 , 7 9 \%}$ \\
\cline { 2 - 3 } & Casa Blanca & $\mathbf{1 8 , 2 7 \%}$ \\
\hline \multirow{2}{*}{ Aender } & Men & $\mathbf{8 0 , 2 \%}$ \\
\cline { 2 - 3 } & Women & $\mathbf{1 9 , 8 \%}$ \\
\hline \multirow{2}{*}{ Marital status } & $<45$ year & $\mathbf{7 4 , 1 1 \%}$ \\
\cline { 2 - 3 } & $>45$ year & $\mathbf{2 5 , 8 9 \%}$ \\
\hline \multirow{2}{*}{ Period of residence } & Married & $\mathbf{6 6 \%}$ \\
\cline { 2 - 3 } & Single & $\mathbf{3 4 \%}$ \\
\hline & $<5$ years & $\mathbf{5 0 \%}$ \\
\cline { 2 - 3 } & $>5$ years & $\mathbf{5 0 \%}$ \\
\hline
\end{tabular}

\subsection{Study of the Satisfaction Test 3.2.1. Dimension 1: Self- satisfaction}

The reliability test expressed in Cronbach's alpha is 0.776 with a mean eigenvalue of 2.638 , so the Fisher test shows a very highly significant difference between the items

\section{3.. Statistical Analysis}

After filtering the data collected, we thought about the statistical analysis of the items (mean score; standard deviation, frequency, etc.) and joined analysis such as the chi2 independence test with 5\% error.

\section{Results}

\subsection{Socio-demographic Characteristics} The respondents chosen in this study ( $80.2 \%$ of men), belong to three Moroccan zones Rabat / Sale / Kenitra $(62.94 \%)$, Tangier / Tetouan $(18.78 \%)$ and the great Casa Blanca $(18.27 \%)$. The average age of the respondents is $32.84 \pm 0.586$ years (minimum age $=18$ and maximum age $=60$ ), of which $74.11 \%$ are under 45 years old. In fact, the average length of stay is $4.74 \pm 0.178$ years, the most recent of which is the one who has spent one year and the oldest has resided for 13 years. On the other hand, $66 \%$ of these students are married compared to $34 \%$ are single (table 2 )

Table 3 Multiple Correlation between Items of Dimension I

$$
\text { **. The correlation is significant at the } 0.01 \text { level (two-tailed). }
$$

\begin{tabular}{llllll}
\hline & Q1 & Q2 & Q3 & Q4 & Q5 \\
\hline Q1 & 1 &, $604^{* *}$ &, $428^{* *}$ &, $449^{* *}$ &, $471^{* *}$ \\
Q2 &, $604^{* *}$ & 1 &, $701 * *$ &, $376^{* *}$ &, $381^{* *}$ \\
Q3 &, $428^{* *}$ &, $701^{* *}$ & 1 &, $343^{* *}$ &, $441^{* *}$ \\
Q4 &, $449^{* *}$ &, $376^{* *}$ &, $343^{* *}$ & 1 &, $606 * *$ \\
\hline
\end{tabular}




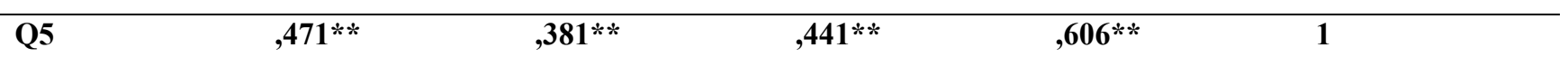

The total score obtained by adding the items of this dimension shows that the mean score is $19.14 \pm 0.24$, with a minimum score of 7 and a maximum score of 25 , the median is 20 . The intergroupspreading translated by the coefficient of variation is $17 ; 92 \%$, a very accepted value. The distribution was found to be Gaussian with a skewness coefficient of 0.524 and a kurtosis coefficient of 0.471 .

Analysis of the respondents' scores according to the transformation model, revealed three distinct categories. Indeed, $13.8 \%(\mathrm{n}=25)$ of Yemeni respondents residing in Morocco showed great dissatisfaction with their self, compared with $16.5 \%(\mathrm{n}=32)$ who responded satisfied with their life, their self, their capacity, not having financial problems or residency problems. However, $69.7 \%(\mathrm{n}=136)$ of respondents are in a risk zone because people in this category can over time convert into the first category or the second category depending on life circumstances.

3.2.2. Dimension II: Relationship / support. / Decision

The reliability test shows that the average cronbach's alpha is 0.730 with an average eigenvalue of 2.41 . The Fisher test shows a significant difference between the items of this dimension (Fisher $=53.95 ; p<0.000$ ). If one of the elements is removed, the cronbach's alpha decreases below the mean value for all the questions asked.

The correlation between the items in Dimension II shows that they are all correlated positively with each other. Those who showed high satisfaction reported having excellent personal relationships and receiving extreme support from family and friends. Thus, these respondents feel happy about their relationship with the family and vice versa (table4).

Table 4 Multiple Correlation between Items in Dimension II

**. The corrélation est significative au niveau 0.01 (bilatéral).

\begin{tabular}{|c|c|c|c|c|c|}
\hline items & Q6 & Q7 & Q8 & Q9 & Q10 \\
\hline Q6 & 1 & ,281 & ,248 &, $459^{* *}$ & ,330 \\
\hline Q7 &, $281^{* *}$ & 1 &, $558^{* *}$ &, $392^{* *}$ &, $372^{* *}$ \\
\hline Q8 &, $248^{* *}$ &, $\mathbf{5 5 8}^{\text {*** }}$ & 1 &, $\mathbf{4 0 3}^{\text {** }}$ & ,269 \\
\hline Q9 &, $459^{* *}$ &, $392^{* * *}$ &, $\mathbf{4 0 3}^{* *}$ & 1 &, $412^{* *}$ \\
\hline Q10 &, $\mathbf{3 3 0}^{* * *}$ &, $372^{* * *}$ &, $269^{* *}$ &, $\mathbf{4 1 2}^{* *}$ & 1 \\
\hline
\end{tabular}

The descriptive analysis shows that the average score for this dimension is $19.05 \pm 0.24$, with a minimum score of 8 and a maximum score of 25 , the median is 19 . The intergroup dispersion expressed by the coefficient of variation is $17.02 \%$, a widely accepted value. The distribution was found to be Gaussian with a skewness coefficient of 0.697 and a kurtosis coefficient of 0.829 .

The analysis of the respondents' scores according to the transformation model revealed three distinct categories. Indeed, $14.8 \%(n=29)$ of Yemeni respondents residing in Morocco showed great dissatisfaction with the support against $13.8 \%(\mathrm{n}=27)$ who responded satisfied with the support of their family and friends. However, $71.4 \%(\mathrm{n}=$
136) of respondents are in a risk zone because people in this category can over time convert into the first or second category depending on their life circumstances.

\subsection{Determining Factors}

Only the "marital status" factor $($ chi2 $=5.49$; $\mathrm{p}<0.05)$ showed a significant association with the categories of this dimension. Really, among single surveyed $19.69 \%$ are dissatisfied against $10.85 \%$ among married. However, the Chi-square test did not show a significant difference between the categories of this dimension I and the other socio-demographic factors (table 5).

Table 5 Chi-square Test between Marital Status and Dimension I Categories

*significant difference at $5 \%$

\begin{tabular}{|c|l|l|l|l|l|l|}
\hline \multicolumn{2}{|c|}{} & $\begin{array}{l}\text { Not } \\
\text { satisfied }\end{array}$ & To minitor & satisfied & $\begin{array}{l}\text { Total } \\
\text { Chi-square } \\
\text { (palue) }\end{array}$ \\
\hline \multirow{2}{*}{ Marital status } & single & 13 & 39 & 14 & 66 & $5,49(p<0,05) *$ \\
\cline { 2 - 7 } & married & 14 & 97 & 18 & 129 & 195 \\
\hline \multicolumn{2}{|l|}{ Total } & 25 & 27 & 136 & 32 & \\
\hline
\end{tabular}

Regarding dimension II, the Chi2 independence test shows a significant link between the factor "city of residence 1" and the categories of this dimension II (chi2 $=8.82 ; \mathrm{p}<0.05)$. The respondents having demonstrated 
dissatisfaction $16.67 \%$ reside in Casa Blanca, $2.7 \%$ in

(table6). Tangier, Tetouan and $17.88 \%$ in Rabat -Sale- Kenitra

Table 6 Chi-square test between "city of residence" and the categories of dimension II

$$
\text { *significant difference at } 5 \%
$$

\begin{tabular}{|l|l|l|l|l|l|l|}
\hline \multicolumn{2}{|c|}{} & Not satisfied & To minitor & satisfied & Total & $\begin{array}{l}\text { Chi-square (p } \\
\text { value) }\end{array}$ \\
\hline \multirow{2}{*}{ city } & casa & 6 & 25 & 5 & 36 & \multirow{8}{*}{$8,82(p<0,05)^{*}$} \\
\cline { 2 - 6 } & Tanger - Tetouan & 1 & 28 & 8 & 37 & \\
\hline \multirow{2}{*}{ Total } & Rabat & 22 & 87 & 14 & 123 & \\
\hline
\end{tabular}

\section{Global Analysis of the Test}

Theanalysis of the correlation between the two dimensions shows that, the latter is significantly associated with a correlation coefficient of $0.71 ; \mathrm{p}$ $<0.000$. Indeed, Yemeni students residing in Morocco have shown great life satisfaction from all perspectivesof health, financial, social and also support by the Moroccan and Yemeni authorities.

\section{Discussion}

The work we have carried out focuses on the state of life satisfaction of Yemeni students residing in morocco. The results obtained for satisfaction show that $13.8 \%(n=25)$ are dissatisfied against $16.5 \%(\mathrm{n}=32)$ who responded satisfied with their life, self, and ability, without having neither financial problems nor residence problem. However, $69.7 \%(n=136)$ are in a watch area. In fact, less people are confronted with material and social difficulties, etc. and they declare themselves satisfied with their life [9]- Quality In fact, given the degraded level of security in Yemen, people find it difficult to earn a living and support their families. Faced with this situation, students are unable to get in touch with their family, which remains the only source of funding or to benefit from the scholarship granted by the Yemeni government. Add to this, the usual problems (loyalty, food, activity, transport ...). This situation allows students to not have an adequate life satisfaction, on the other hand [10-12].

\section{5. conclusion}

The study we carried out with Yemeni nationals residing in Morocco, the majority of whom are students, made it possible to focus on their living conditions and especially during the period of confinement. the results show the clear satisfaction of these respondents with respect to the behavior of the Moroccan authorities with regard to the daily needs which were in the form of food; services, care .... etc.

\section{References}

1. Enquête Conditions de vie des étudiants OVE(2016)

2. L. Harvey, Student Feedback: A Report to the Higher Education Funding Council for England, Centre for Research into Quality », The
University of Central England in Birmingham, Perry Barr, Birmingham, UK. (2001)

3. G. Lee, N. Jolly, B. Kench, Gelonesi, Factors Related to Student satisfaction with University, 4th Pacifi c Rim, First Year in Higher Education Conference 1-8.(2000)

4. M. Benjamin, A. Hollings, Student satisfaction ", Journal of College Student Development, 38 (3): 213.(1997).

5. N. Öngider, I. Yüksel, dokuz Eylül Üniversitesi Öğrencilerinin Psikolojik Gerek sinimlerinin Belirlenmesi Üzerine Birİnceleme ", Türk Psikoloji Bülteni, Şubat.(2002)

6. K.S. Cameron, Domains of Organizational Effectiveness in Colleges and Universities, Academy of Management Journal, 24: 2447.(1981)

7. S.M. Laouali, J.B. Meyer, Le Maroc, pays d'accueil d'étudiants étrangers. p. 114-123 https://doi.org/10.4000/hommesmigrations.931, (2015)

8. M. Leclerc-Olive,G.S. Ghella, A.C. Wagner,Les Mondes universitaires face au marché : circulation des savoirs et pratiques des acteurs, Paris, Karthala, (2011)

9. Institut national de la statistique et des études économiques «Satisfaction et qualité de vie » Économie et Statistique $n^{\circ}$ 469-470, (2014)

10. R. Gilman, E.S. Huebner, J.E. Laughlin, A first study of the Multidimensional Students' Life Satisfaction Scale with adolescents. Social IndicatorsResearch. 52 : 135-160, (2000)

11. P.J. Greenspoon, D. Saklofske, Toward an integration of subjective well-being and psychopathology. Social IndicatorsResearch. $54: 81-108$, (2001)

12. Ichaka Camara,Conditions de vie et d'études de « migrants étudiants » africains en URSS et en Russie : quels facteurs ont pu contribuer à leurs difficultés et à leurs stratégies d'adaptation ?. Journal of international Mobility 2018/1. $6: 45-75,(2018)$ 